\title{
A Study of the Correlation Between Dyslipidemia and Iron Deficiency Anemia in Egyptian Adult Subjects
}

\author{
Mai A. Gharib ${ }^{1}$, Nahed S. Abd Elalal ${ }^{2}$ and Yousif A. Elhassaneen ${ }^{1 *}$
}

\begin{abstract}
Background: Both iron deficiency anemia (IDA) and dyslipidemia are widely prevalent public health problems, especially in the Egyptian population. So, the purpose of this research was to study the correlation between dyslipidemia and IDA in Egyptian adults, Minoufiya Governorate population. Methods: In this comparative cross-sectional study, 110 adult with confirmed IDA and 110 healthy controls, in the age group 18-55 years were investigated for any possible changes in serum lipid profile i.e., triglycerides (TG), total cholesterol (TC), high density lipoprotein cholesterol (HDL-c) and low density lipoprotein cholesterol (LDL-c) and very low density lipoprotein cholesterol (VLDL-c). Also, correlation between serum lipid profile and severity of anemia was also calculated. Results: The results are shown as mean \pm standard deviation. TG, TC, LDL-c and VLDL-c levels were found to be significantly $(P<0.001)$ elevated in the IDA group (were $85.67 \pm 26.86,123.79 \pm 30.54,71.57 \pm 24.64$ and 17.13 $\pm 7.21 \mathrm{mg} / \mathrm{dl}$ ) as compared to controls $(107.89 \pm 22.40,158.45 \pm 26.34,93.24 \pm 18.45$ and $21.58 \pm 5.76$ $\mathrm{mg} / \mathrm{dl})$. whereas level of HDL-c were found to be significantly $(P<0.001)$ higher in patients $(43.63 \pm 12.54$ $\mathrm{mg} / \mathrm{dl})$ as compared to controls $(35.09 \pm 13.05 \mathrm{mg} / \mathrm{dl})$. Correlation between lipid profile (TG, TC, and LDL) levels and severity of anemia (hemoglobin levels) showed positive and significant $(P<0.01)$ values. Conclusion: These findings indicate that that the levels of serum lipid profile in Egyptian adults IDA were lower than the healthy control. However, to identify potential mechanisms of this relationship, further research are recommended to be carried out.
\end{abstract}

Keywords: Iron deficiency anemia, serum lipid profile, hemoglobin, ferritin, cholesterol, severity of anemia.

\section{INTRODUCTION}

Iron- deficiency anemia or what is called (IDA) is initially defined as a decrease in the amount of hemoglobin $(\mathrm{Hb})$ or red blood cells (RBCs) in the blood (Wang et al., 3013). The most prevalent type of anemia is IDA, which happens when the body does not have enough of the mineral iron to make haemoglobin. The rest of the body can't obtain the oxygen it needs if there isn't enough iron in the bloodstream. According to the World Health Organization (WHO), IDA is generally characterized by a level of $\mathrm{Hb}$ which is below $13.0 \mathrm{~g} / \mathrm{dL}$ in male adults, and $12.0 \mathrm{~g} / \mathrm{dL}$ in female adults who are not pregnant, and below $11.0 \mathrm{~g} / \mathrm{dL}$ in pregnant women (WHO, 2011). As a result, a decrease in blood iron produces insufficient $\mathrm{Hb}$ synthesis and, as a result, a decrease in erythrocyte proliferation. In patients with IDA, there may also be a decline in red cell survival (Hafez et al., 1986 and Cusick et al., 2008). Accordingly, the most common causes of IDA might include inadequate iron intake due to a diet that doesn't provide the daily nutritional needs or that's heavily restricted; inflammatory bowel disease; increased iron requirements during pregnancy; or blood loss through heavy periods or internal bleeding (Elashiry et al., 2014; Cappellini et al., 2019 and Mehram et al., 2021).

For these reasons, IDA is considered to be one of the major health problems. According to the WHO (2015) 1.62 billion individuals, or 24.8 percent of the world's population, suffer from anemia. Iron deficiency is responsible for roughly half of all anemia cases worldwide, and it kills over 841,000 people per year (Longo et al., 2011). Anemia and iron deficiency affect a large percentage of the population in various age groups, according to a study conducted by For example, in the United States, anemia affects almost 4.7 million people, and its incidence rises with age, with $44.4 \%$ of people over 85 being anaemic (Brill and Baumgardner, 2000). In Egypt; however, anemia was a public health problem where the prevalence of it reached $40 \%$ (EDHS, 2005). In this line, Elashiry et al. (2014) noted that anemia by the third trimester of pregnancy is a major health problem, with personal, nutritional, and some components of outcome healthcare offered at this point all contributing to the risk. Also, Afaf et al. (2015) reported that among the 4526 households from eleven Egyptian governorates $18.5 \%$ of IDA was recognized as IDA with a high prevalence for mothers (25.1\%). Furthermore, Al Ghwass et al. (2015) discovered that IDA is a serious public health issue in Egyptian children, particularly in rural areas, those from poor social classes, and those with low maternal educational levels.

DOI: 10.21608/asejaiqjsae.2022.219631

${ }^{1}$ Department of Nutrition and Food Science,

Faculty of Home Economics, Minoufiya University, Shebin El-Kom, Egypt;

${ }^{2}$ Department of Home Economics,

Faculty of Specific Education, Zagazig University, Zagazig, Egypt.

${ }^{1 *}$ Corresponding author: yousif12@ hotmail.com

Received January 10, 2022, Accepted, February 13, 2022. 
On the other hand, dyslipidemia refers to unhealthy levels of one or more kinds of lipid in the blood. Blood contains three main types of lipid including highdensity lipoprotein (HDL), low-density lipoprotein (LDL), and triglycerides (TG). Most dyslipidemias are hyperlipidemias, that is, an elevation of lipids (LDL and/or TG) and reduction of HDL in the blood (Voet, D. and Voet, 1990 and Chou et al., 2016). Elevation of serum lipid levels, dyslipidemia, increases the risk of atherosclerosis and coronary heart disease (Yang et al., 2015). Because of the role of dyslipidemia in atherogenesis, its effects on health increase with age, thus great attention is paid to dyslipidemia and its associated factors (Salonen et al., 1992; Sotuneh et al., 2014; Ashar et al., 2015). The number of papers published on lipid changes, or dyslipidemia, in IDA is relatively few. Furthermore, the findings of these investigations are inconclusive. Some of these studies demonstrate that lipid values in IDA patients are greater than in healthy controls, whereas others show that lipid parameters in IDA patients are lower (Ohira et al., 1980; Choi et al., 2001, and Jingqi et al., 2020). They also showed that after iron replacement or transfusion, lipid markers in IDA patients improved to normal levels. Other epidemiological studies, on the other hand, have linked substantial iron reserves in the body to an increased risk of coronary heart disease, with dyslipidemia being the most relevant risk factor (Avila et al., 2015 and Guglielmi et al., 2015). Moreover, Furthermore, Mahshid et al. (2017) found that the amount of lipid profile (triglyceride and cholesterol) in older adults with anemia and IDA was lower than in the general population. Although a link between IDA and dyslipidemia has been shown in animal models, this link has not been well investigated in people (Bristow-Craig et al., 1994 and Ahmed et al., 2012). The current study aims to evaluate the association between IDA and dyslipidemia in Egyptian adults because there have been few investigations on the influence of anemia on serum lipid profile.

\section{MATERIAL AND METHODS}

\section{Materials}

All chemicals, solvents and buffers, except stipulated, were in analytical grade and purchased from Al-Gomhoria Company for Trading Drugs, Chemicals and Medical Instruments.

\section{Study protocol}

The study was conducted from September 2019 to March 2020, in Health Units, Hospitals and Teaching Hospitals in Minoufiya Governorate, Egypt. The study protocol was approved by the Local Scientific Research Ethics Committee (SREC/HE/03/2019), Faculty of Home Economics, Minoufiya, Shebin El-Kom, Egypt.
A total of 220 subjects aged 25 to 50 years who were seeking medical advice for mild acute complaints as upper respiratory tract infections, mild gastroenteritis or other complaints, were chosen in randomization and enrolled in the study.

Subjects with any history of smoking, disease of kidney, heart, liver or thyroid, diabetes mellitus, chronic infection/disease, hypertension, history of drug therapy, hematinic therapy especially during past on year, both long term and those affecting serum lipid level steroids, active bleeding, hematological disorder, recurrent jaundice, current pregnancy and passage of worms in stools, hospitalization or any surgical procedure performed within past three months, history of blood transfusion within 6 months before the study, and usage of supplemental vitamins were excluded from the study (Ann et al., 2002; Bermejo and García-López , 2009).

The study methodology was explained to all of the participants, and their written agreement was collected. Online statistical calculator was used for sample size determination guided by power test of $80 \%$, confidence level of $95 \%$, and $\alpha$ error of $5 \%$. The sample size was calculated to be 220 subjects. They were given particular days to take venous blood samples early in the morning after fasting the night before. The haematological and biochemical parameter reference values were derived from hospital laboratory data. All subjects had their complete hemogram, serum iron, serum ferritin, total iron binding capacity (TIBC), and mean corpuscular volume (MCV) measured. When haemoglobin $(\mathrm{Hb})$, serum iron levels, and serum ferritin levels were lower below the predicted values for the selected group, the diagnosis of IDA was confirmed. Description criteria for IDA are microcytic hypochromic erythrocytes; with a mean corpuscular volume (MCV) <70 fL, red blood cell distribution width $(\mathrm{RDW}) \geq 15 \%$, hemoglobin concentration $<11 \mathrm{~g} / \mathrm{dL}$, serum iron concentration $<40 \mu \mathrm{g} / \mathrm{dL}$, and serum ferritin concentration $<10 \mu \mathrm{g} / \mathrm{dL}$. A field pretested interviewing questionnaire was used for data collection which covering the following points: subject age, sex, residence (urban or rural) and family size. Sociodemographic status of subjects and their families and socioeconomic score, which contained social variables were calculated and classified such as mentioned by Fahmy and El-Sherbini (Fahmy and ElSherbini, 1983).

\section{Hematological analysis}

Blood samples were withdrawn from the antecubital vein into glass centrifuge tubes containing oxalate solution (1.34\%) as anticoagulant. After centrifugation at $1500 \mathrm{Xg}$ for 10 minutes, plasma was withdrawn and used for analysis of serum lipid parameters (Singh et al., 1991). Triglycerides (TG), Total cholesterol (TC) and 
HDL-Cholesterol were determined in serum using specific kits purchased from El-Nasr Pharmaceutical Chemicals Company, Cairo, Egypt. Low density lipoprotein cholesterol (LDL-c) and very low density lipoprotein cholesterol (VLDL-c) were assayed according to the equations of Fniedewald et al., (1972) as follow: Very low density lipoprotein (VLDL cholesterol) $=\mathrm{TG} / 5$ and $\mathrm{LDL}$ cholesterol $=$ Total cholesterol - HDL cholesterol - V LDL cholesterol.

Serum iron $(\mathrm{Fe})$ content samples were determined by the adaptation the method mentioned by Singh et al. (1991). Blood hemoglobin (Hb) concentration was determined using cyanmethemoglobin method according to Villanova (Villanova, 1994). The plasma ferritin concentrations value was assayed using specific Kits (Al-Gomhoria Company for Trading Drugs, Chemicals and Medical Instruments, Cairo, Egypt) according to the methods mentioned in Tietz (1999). The complete blood count was done using Coulter 1660 to determine the erythrocyte indices including mean corpuscular volume [MCV].

\section{Statistical analysis}

The Pearson method was used to determine the statistical analysis using the MINITAB-12 computer programme (Minitab Inc., State College, PA). The unpaired Student's ' $t$ ' test was used to compare the control and IDA groups. The results were expressed as means \pm standard deviation (SD). A $P$ value of less than 0.05 was accepted as the statistical significance level.

\section{RESULTS AND DISCUSSION}

\section{Sociodemographic characteristics and multivariate analysis of potential risk factors for IDA among studied group}

Among 237 participants were included in the study, $17(7.17 \%)$ participants were not analyzed because of unavailability of consent for study or inadequate sample. The remaining enrolled 220 subjects which include 110 cases and 110 controls, aged 25 to 55 years with a mean age of $42.34 \pm 5.23$ years. They were 105 $(47.73 \%)$ males and $115(52.27 \%)$ females. The sociodemographic data and multivariate analysis of potential risk factors for IDA among studied group are shown in Table (1). Based on the biochemical iron status, 110 subjects $(50.00 \%)$ were anemic. Of 110 cases, 37 had hemoglobin $<7 \mathrm{~g} \%$, 48 had hemoglobin between 7 and $10 \mathrm{~g}$, and 25 had hemoglobin more than $10 \mathrm{~g} \%$. Based on the red cell indices, 58 had microcytic hypochromic anemia, 36 had normochromic anemia, 11 had dimorphic anemia, 4 had normocytic hypochromic anemia, 1 each had macrocytic anemia and pancytopenia. As shown in the same data, a logistic regression model was used to assess the effects of the significant explanatory variables in order to distinguish predictors of IDA. It was found that subjects from rural areas $(77.00 \%)$, those from low social class $(45.46 \%)$ and those of secondary mothers (30.91) were the significant risk factors for IDA in these subjects. In similar study carried out by Amany and Samaa (2012) and Mehram et al. (2021) found that multivariate analysis revealed that, low level of education, decreased birth spacing and history of anemia before pregnancy were associated with increased risk of anemia $(\mathrm{p}<0.05$, $\mathrm{OR}=18.821,10.582$ and 3.362 respectively). Also, $\mathrm{Wu}$ et al. (2002) reported that iron deficiency is responsible for lost productivity and premature death in adults and has been implicated as a cause of perinatal complications such as low birth weight and premature delivery in affected mothers (CDCP, 2008). The first signs and symptoms in youngsters can be mild and treatable. Increased vulnerability to infection and poor growth are two long-term effects of iron deficiency. Finally, Elhassaneen et al. (2016) found that patients from rural areas $(68.12 \%)$, those from low social class $(65.63 \%)$ and those of illiterate mothers (82.46) were the significant risk factors for IDA in Egypt.

\section{Hematological and biochemical parameters of the groups}

The hematological and biochemical parameters among control (normal cases) and IDA patients are shown in Table (2). From such data it could be noticed tha the mean hemoglobin $(\mathrm{Hb})$ level and mean corpuscular volume (MCV) of control were 13.80 \pm 2.4 $\mathrm{g} / \mathrm{dL}$ and $78.99 \pm 6.72 \mathrm{fL}$ which significantly decreased by the rates of $-48.77 \%(\mathrm{p} \leq 0.001)$ and $-24.41 \%(\mathrm{p} \leq 0.01)$ in IDA patients, respectively. On the other side, iron profile among control (normal cases) and IDA patients indicated that the mean serum iron and serum ferritin levels of normal cases were $130.56 \pm 23.78 \mu \mathrm{g} / \mathrm{dl}$ and $78.56 \pm 18.54 \mu \mathrm{g} / \mathrm{dl} \quad$ which significantly $(\mathrm{p} \leq 0.001)$ decreased by the rates of $-68.42 \%$ and $-90.52 \%$ $(p \leq 0.001)$ in IDA patients, respectively. Such data are partially in accordance with that obtained by Elhassaneen et al. (2016) who studied the prevalence of IDA in Infants and Young Children of Port Said Governorate in Egypt. Such as mentioned by Ann et al. (2002) measurement of $\mathrm{Hb}$ is a more sensitive and direct test for anemia than others tests. MCV, the average volume of RBCs, is reported in automated analyses, but it also can be calculated as the ratio of hematocrit (Hct) to RBC count. It is useful for categorizing anemia as microcytic, normocytic, and macrocytic. Serum iron concentration can be measured directly and generally decreases as iron stores are depleted (Fairbanks, 1991). Serum iron, on the other hand, may not correctly reflect iron storage since it is impacted by a number of other factors, including infection, iron absorption from food, inflammation, and diurnal variation (Oski, 1993 and Ann et al., 2002). Ferritin is a storage compound for iron, and serum 
ferritin levels normally correlate with total iron stores (Ann et al., 2002). As iron stores are depleted, serum ferritin levels decline and are the earliest marker of ID. Additionally, Douglas and Etheresia (2014) reviewed that serum ferritin is an important inflammatory and chronic infection disease marker, as it is mainly a leakage product from damaged cells.

Table 1. Sociodemographic characteristics and multivariate analysis of potential risk factors for IDA among studied group

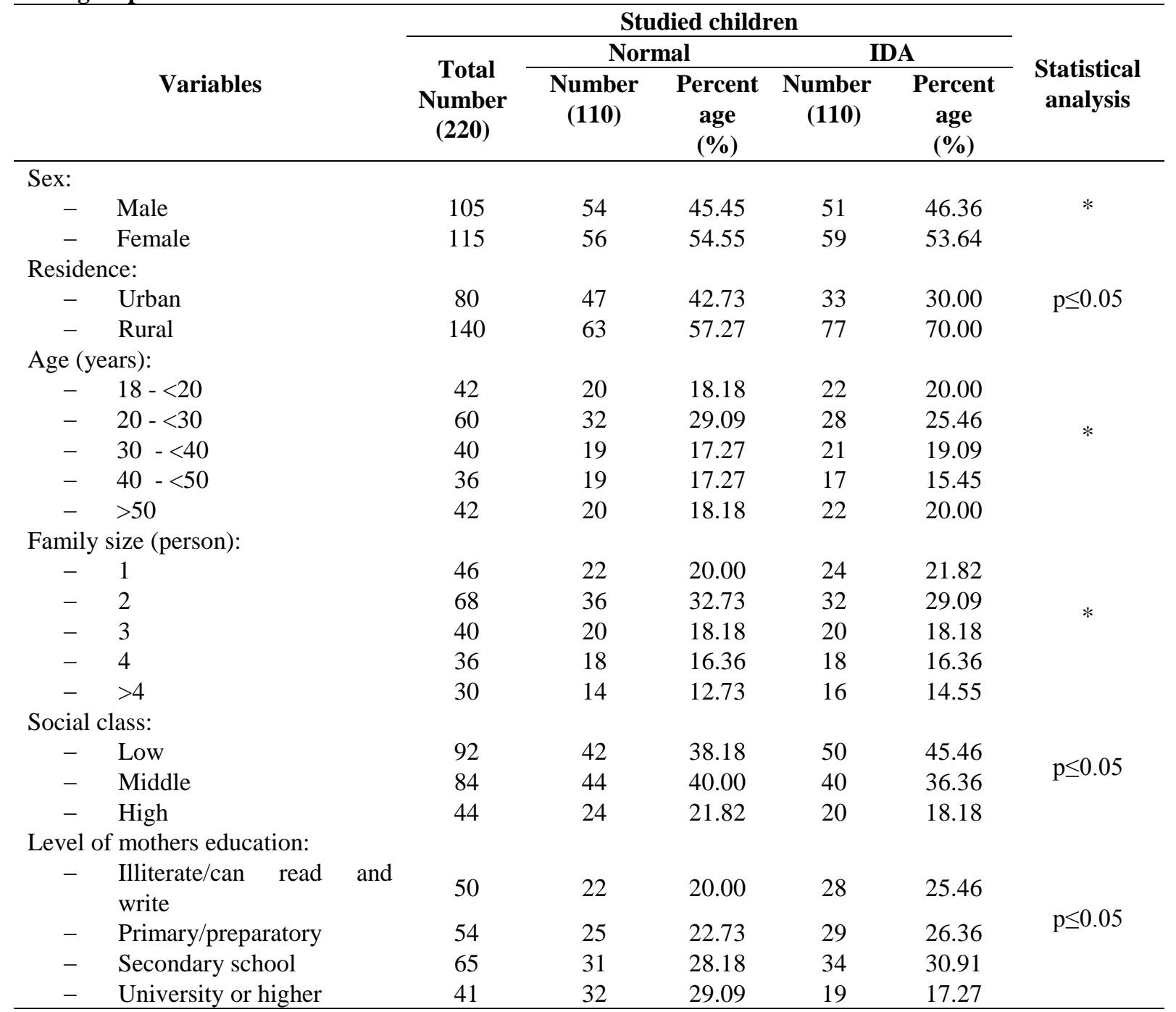

* Non-significant $(P \leq 0.05)$ 
Table 2. Hematologic al parameters of control (No Anemia) and IDA patients

\begin{tabular}{|c|c|c|c|c|}
\hline \multicolumn{2}{|c|}{ Parameters } & $\begin{array}{c}\text { Control (No } \\
\text { anemia, } n=110)\end{array}$ & $\underset{(n=110)}{\text { IDA }}$ & Statistical analysis \\
\hline \multirow{3}{*}{$\mathrm{Hb}(\mathrm{g} / \mathrm{dL})$} & Range & $12.02-15.98$ & $6.25-9.21$ & \multirow{3}{*}{$\mathrm{p}<0.001$} \\
\hline & Mean \pm SD & $13.80 \pm 2.4$ & $7.07 \pm 2.11$ & \\
\hline & $\%$ of change & ------ & $-48.77 \pm 3.01$ & \\
\hline \multirow{3}{*}{$\mathrm{MCV}(\mathrm{fL})$} & Range & $72.98-89.56$ & $56.83-67.42$ & \multirow{3}{*}{$\mathrm{p}<0.01$} \\
\hline & Mean \pm SD & $78.99 \pm 6.72$ & $59.71 \pm 5.42$ & \\
\hline & $\%$ of change & ------ & $-24.41 \pm 4.98$ & \\
\hline \multirow{3}{*}{ Serum iron $(\mu \mathrm{g} / \mathrm{dL})$} & Range & $97.94-149.72$ & $29.97-52.89$ & \multirow{3}{*}{$\mathrm{p}<0.001$} \\
\hline & Mean \pm SD & $130.56 \pm 23.78$ & $41.23 \pm 15.67$ & \\
\hline & $\%$ of change & ----- & $-68.42 \pm 14.60$ & \\
\hline \multirow{3}{*}{$\begin{array}{l}\text { Serum ferritin } \\
\qquad(\mu \mathrm{g} / \mathrm{dL})\end{array}$} & Range & $60.52-112.21$ & $6.97-9.10$ & \multirow{3}{*}{$\mathrm{p} \leq 0.001$} \\
\hline & Mean \pm SD & $78.56 \pm 18.54$ & $7.45 \pm 2.94$ & \\
\hline & $\%$ of change & ----- & $-90.52 \pm 7.64$ & \\
\hline
\end{tabular}

\section{Comparison of serum lipid profile between normal and IDA groups}

The comparison of serum lipid profile between normal and IDA groups are shown in Table (3) and Figure (1). From such data it could be noticed that the mean TG, TC, LDL-c and VLDL-c in control are $107.89 \pm 22.40, \quad 158.45 \pm 26.34, \quad 93.24 \pm 18.45$ and $21.58 \pm 5.76 \mathrm{mg} / \mathrm{dL}$, and in IDA were $85.67 \pm 26.86$, $123.79 \pm 30.54,71.57 \pm 24.64$ and $17.13 \pm 7.21 \mathrm{mg} / \mathrm{dL}$, respectively. Mean HDL-c levels was $35.09 \pm 13.05$ $\mathrm{mg} / \mathrm{dL}$ in control group and $43.63 \pm 12.54 \mathrm{mg} / \mathrm{dL}$ in IDA group. The differences between two groups with regard to the all serum lipid profile fractions levels were statistically significant; all the values except HDL-c being lower in IDA group. Such data are in accordance partially with that observed by Chowta et al. (2017). Also, Choi et al. (2001) observed that no significant differences in serum lipid levels between cases with moderate IDA and normal controls (healthy). They also found that serum TC and TG level were significantly lower in severely anemic subjects ( $\mathrm{Hb}<8.0 \mathrm{~g} / \mathrm{dL}$ ) compared to normal controls which return to normal following iron supplementation. Furthermore, in the severely anemic subjects, blood hemoglobin concentration was positively correlated with serum TC and TG levels (Ece et al., 1999; Sandeep et al., 2014). On the other side, some studies were reported data in contrast to our findings. For example, Yang et al. (2015) showed higher levels of TG and lower HDL-c levels in the IDA women. In addition, Antappanavar et al. (2014) found that in cases with IDA, TG and VLDL-c levels were significantly higher than in normal controls, although LDL-c levels were significantly lower. Furthermore, Jingqi et al. (2020) discovered that genetically predicted greater blood iron levels are linked to a lower risk of IDA, lipid metabolism

disorders, and its two subtypes, hyperlipidemia and hypercholesterolemia. They are consistently linked to decreased TC and LDL-c levels in the blood. All of the available evidence suggests that iron deficiency has an influence on the lipid and lipoprotein profile. Other factors, in addition to iron deficiency, may play a role in such a problem. A diet lacking in iron, for example, may also be lacking in calories and protein. As a result, a hypocaloric diet may result in hypolipidemia (Aydin et al., 1999). Also, Morrison et al. (1980) discovered that plasma LDL-C was adversely connected with the dietary polyunsaturated fatty acids (PUFA)/saturated fatty acids (SFA) ratio, and that TC and LDL-C were negatively correlated with dietary carbohydrate. Furthermore, Gonzales-Requejo et al. (1995) discovered that high total fat consumption was linked to an increase in serum levels of TC, LDL-C, and HDL-C. The altering lipid profile in children with IDA could be due to a variety of macronutrient intakes. Additionally, Mensink and Katan (1989) discovered that high MUFA consumption as a percentage of total fat intake is linked to reduced TC and LDL-C levels. 
Table 3. Comparison of serum lipid profile between normal and IDA groups

\begin{tabular}{lcccc}
\hline & Parameters & $\begin{array}{c}\text { Normal group } \\
(\mathbf{n = 1 1 0})\end{array}$ & $\begin{array}{c}\text { IDA group } \\
(\mathbf{n}=\mathbf{1 1 0})\end{array}$ & Statistical analysis \\
\hline $\mathrm{TG}$ & Range & $92.56-135.67$ & $59.67-110.54$ & \\
$(\mathrm{mg} / \mathrm{dL})$ & Mean \pm SD & $107.89 \pm 22.40$ & $85.67 \pm 26.86$ & $\mathrm{p} \leq 0.001$ \\
& \% of change & 0.00 & $-20.60 \pm 4.67$ & \\
$\mathrm{TC}$ & Range & $120.67-181.65$ & $98.56-160.43$ & $\mathrm{p} \leq 0.001$ \\
$(\mathrm{mg} / \mathrm{dL})$ & Mean \pm SD & $158.45 \pm 26.34$ & $123.79 \pm 30.54$ & \\
$\mathrm{HDL}-\mathrm{c}$ & \% of change & 0.00 & $-21.87 \pm 3.07$ & \\
$(\mathrm{mg} / \mathrm{dL})$ & Range & $24.87-46.90$ & $37.11-57.28$ & $\mathrm{p} \leq 0.001$ \\
& Mean $\pm \mathrm{SD}$ & $35.09 \pm 13.05$ & $43.63 \pm 12.54$ & \\
$\mathrm{LDL}-\mathrm{c}$ & \% of change & 0.00 & $24.34 \pm 4.12$ & $\mathrm{p} \leq 0.001$ \\
$(\mathrm{mg} / \mathrm{dL})$ & Range & $70.10-100.54$ & $42.67-93.20$ & \\
& Mean \pm SD & $93.24 \pm 18.45$ & $71.57 \pm 24.64$ & $\mathrm{p} \leq 0.001$ \\
$\mathrm{VLDL}-\mathrm{c}$ & \% of change & 0.00 & $-23.25 \pm 6.03$ & \\
$(\mathrm{mg} / \mathrm{dL})$ & Range & $17.89-27.67$ & $12.65-26.44$ & $17.13 \pm 7.21$ \\
\end{tabular}

TG, triglycerides; TC, total cholesterol; HDL-c, high density lipoprotein cholesterol; LDL-c, low density lipoprotein cholesterol and VLDL-c, very low density lipoprotein cholesterolncv.

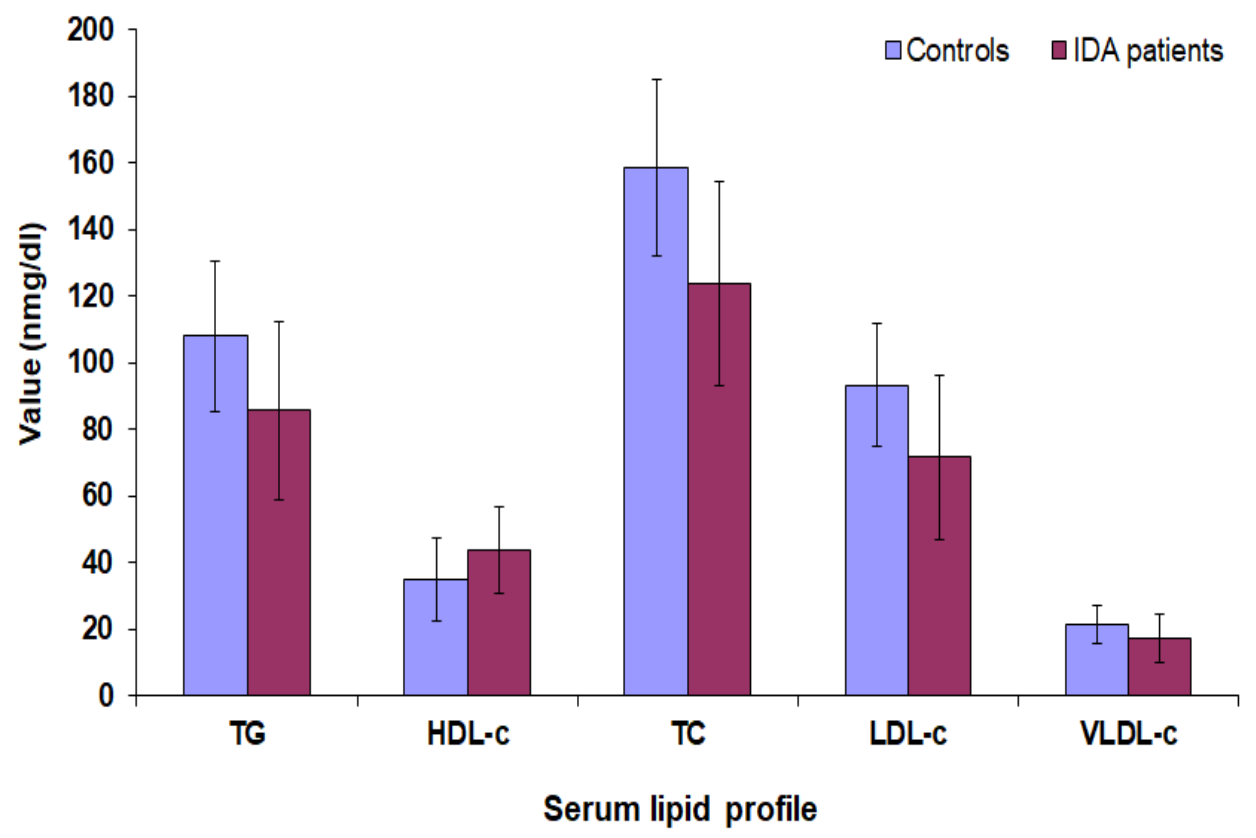

Fig. 1. Serum lipid profile in normal and IDA groups

TG, triglycerides; TC, total cholesterol; HDL-c, high density lipoprotein cholesterol; LDL-c, low density lipoprotein cholesterol; VLDL-c, very low density lipoprotein cholesterol 


\section{Correlation between lipid profile and different grades of anemia}

Correlation between lipid profile and severity of anemia of studied cases was shown in Table (4) and Figure (2). The comparison of lipid profile values among IDA with different grades of anemia showed statistical significance for TG, TC, and LDL, the values being positively correlating with levels of hemoglobin. Thus, as the severity of anemia increased, there was a proportionate decrease in the lipoprotein values which suggesting that the association of anemia with hypocholesterolemia. Such date are in accordance with that reported by Choi et al. (2001) who found that serum TC level is positively correlated with the hemoglobin levels in IDA group. Also, Ali et al. (2007) reported that in premenopausal women both low iron states and anemia itself may play protective roles for atherosclerotic heart diseases via improved lipid metabolism. Such phenomena, positively correlation between serum lipid profile and levels of hemoglobin, could be interpreted by one or more of the following mechanisms: 1), the concentration of red blood cells may affect cholesterol synthesis or mobilization from tissue to plasma (Ohira et al.,1980). It has been reported that the activity of some enzymes such as thyroid peroxidase decrease in iron deficient states which might also decrease the activity of enzymes contributing to cholesterol synthesis (Hess et al., 2002), 2) Iron plays a role in hepatic lipogenesis (Voet and Voet, 1990). Because iron is a key component of various lipidmetabolizing enzymes and transporters, it may have a direct impact on hepatic lipid metabolism, 3) Iron in its ferrous form can generate free radicals, leading to oxidative stress and lipid peroxidation (Ahmed et al., 2012), and 4) Finally, increasing hepatic iron stores resulted in overexpression of multiple enzymes, including the rate-limiting enzyme in cholesterol production, which boosted liver cholesterol synthesis and levels (Graham et al., 2010).

Table 4. Correlation between lipid profile and different grades of anemia

\begin{tabular}{|c|c|c|c|c|}
\hline \multicolumn{2}{|c|}{ Parameters } & \multicolumn{3}{|c|}{ Hemoglobin level (g/dL) } \\
\hline & & $<7(n=37)$ & $7-10(n=48)$ & $>10(n=25)$ \\
\hline \multirow{2}{*}{$\begin{array}{l}\text { TG } \\
(\mathrm{mg} / \mathrm{dL})\end{array}$} & Range & $48.89-106.89$ & $65.78-112.76$ & $75.67-98.41$ \\
\hline & Mean \pm SD & $74.54 \pm 28.16^{b}$ & $92.13 \pm 24.11^{\mathrm{a}}$ & $90.54 \pm 10.98^{a}$ \\
\hline \multirow{2}{*}{$\begin{array}{l}\text { TC } \\
(\mathrm{mg} / \mathrm{dL})\end{array}$} & Range & $81.67-137.67$ & $98.76-140.45$ & $115.23-140.26$ \\
\hline & Mean \pm SD & $103.43 \pm 27.63^{b}$ & $124.19 \pm 20.65^{\mathrm{a}}$ & $129.46 \pm 16.56^{a}$ \\
\hline \multirow{2}{*}{$\begin{array}{l}\mathrm{HDL}-\mathrm{c} \\
(\mathrm{mg} / \mathrm{dL})\end{array}$} & Range & $24.24-50.20$ & $33.67-51.26$ & $20.56-42.87$ \\
\hline & Mean \pm SD & $37.56 \pm 15.32^{a}$ & $34.87 \pm 16.32^{a}$ & $36.50 \pm 12.56^{a}$ \\
\hline \multirow{2}{*}{$\begin{array}{l}\text { LDL-c } \\
(\mathrm{mg} / \mathrm{dL})\end{array}$} & Range & $44.76-70.98$ & $55.67-80.11$ & $63.78-76.56$ \\
\hline & Mean \pm SD & $53.96 \pm 24.90^{b}$ & $67.89 \pm 16.98^{a}$ & $74.85 \pm 15.78^{a}$ \\
\hline \multirow{2}{*}{$\begin{array}{l}\text { VLDL-c } \\
(\mathrm{mg} / \mathrm{dL})\end{array}$} & Range & $8.45-23.56$ & $11.67-21.67$ & $12.67-24.10$ \\
\hline & Mean \pm SD & $14.91 \pm 8.11^{\mathrm{a}}$ & $18.43 \pm 5.98^{\mathrm{a}}$ & $18.11 \pm 7.40^{\mathrm{a}}$ \\
\hline
\end{tabular}

TG, triglycerides; TC, total cholesterol; HDL-c, high density lipoprotein cholesterol; LDL-c, low density lipoprotein cholesterol and VLDL-c, very low density lipoprotein cholesterol 


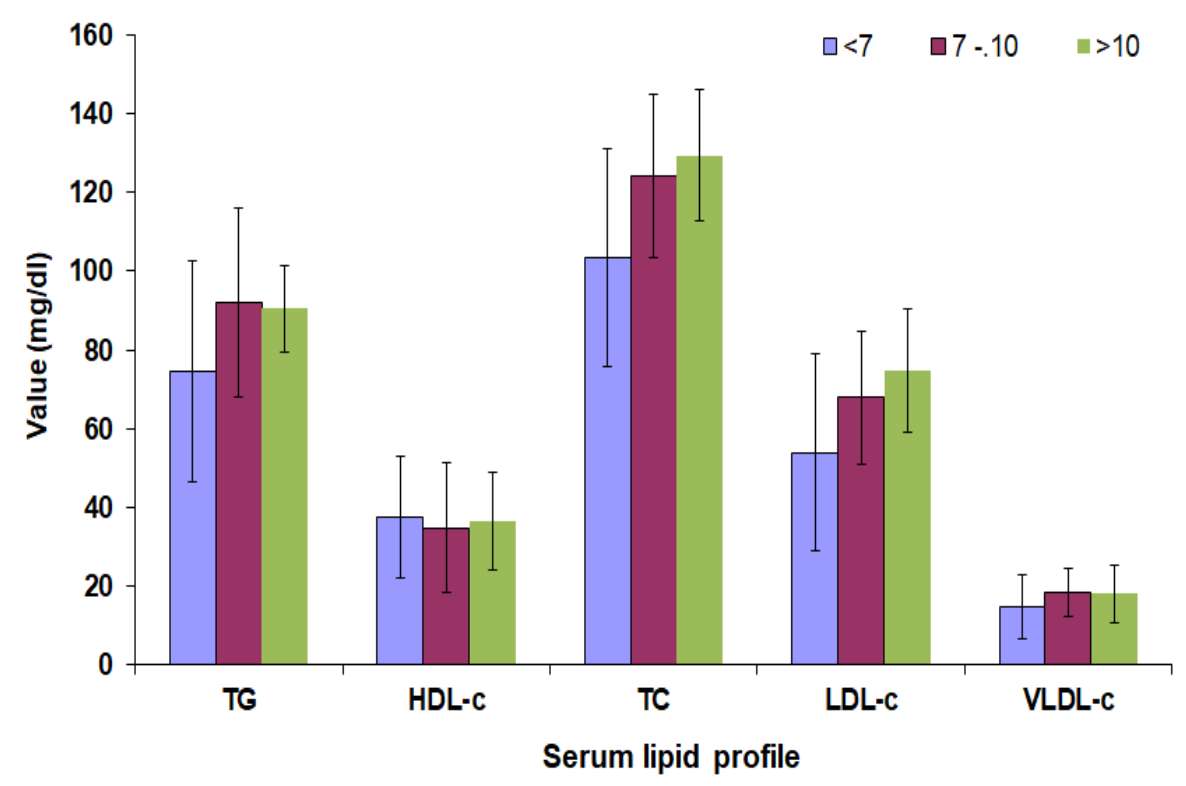

Fig. 2. Serum lipid profile and different grades of anemia

TG, triglycerides; TC, total cholesterol; HDL-c, high density lipoprotein cholesterol; LDL-c, low density lipoprotein cholesterol and VLDL-c, very low density lipoprotein cholesterol

\section{CONCLUSION}

The results of the present study showed that the values of serum lipid profile including triglyceride, cholesterol, high density lipoprotein and low density lipoprotein in Egyptian adults iron deficiency anemia were lower than the control, which is consistent with the findings of some other previous studies. However, to identify potential mechanisms of this relationship, further studies are recommended to be carried out.

\section{ACKNOWLEDGEMENTS}

The authors acknowledge and appreciate the great assistance of Dr. Ali Abdallah Hassan, Nutrition Administration, Menoufia University Hospitals, Shebin El-Kom, Egypt.

\section{COMPETING INTERESTS}

The authors declare that they have no competing interests.

\section{REFERENCES}

Afaf, A.T., T.H. Emily and M.A. Awatif. 2015. Anemia and Iron Deficiency Anemia in Egypt. IOSR J. Pharm. 5: 3034.

Ahmed, U., P.S. Latham and P.S. Oates. 2012. Interactions between hepatic iron and lipid metabolism with possible relevance to steatohepatitis. World J. Gastroenterol.18: 4651-4658.
Al Ghwass, M., E. Halawa, S. Sabry and D. Ahmed. 2015. Iron deficiency anemia in an Egyptian pediatric population: A cross-sectional study. Ann. Afr. Med. 14:25-31.

Ali, O., S. Can, S. Umut and R. Funda. 2007. The Relationship Between Iron Deficiency Anemia and Lipid Metabolism in Premenopausal Women. Am. J. Med. Sci. 334:331-333.

Amany, M and S. Samaa. 2012. Prevalence and Risk Factors of Anemia among a Sample of Pregnant Females Attending Primary Health Care Centers in Makkah, Saudi Arabia. Pak. J. Nutr. 11. 1113-1120.

Ann, W., L. Leann and B. Henry. 2002. Screening for Iron Deficiency. Pediatrics in Review, 23: 171-178.

Antappanavar, V.B., S.G. Biradar, V. Patil, P.M. Biradar, S. Mithare and A.K. Sharma. 2014. A study of correlation between iron deficiency anemia and serum lipid profile in Indian adults in BRIMS, Bidar. Int. J. Adv. Med. 1:96100.

Ashar, S., S. Sultan, S.M. Irfan and A. Sheeraz. 2015. Serum fasting lipid profile in children and adolescents with $\beta$ thalassaemia majorin southern Pakistan. Malays J. Pathol. 37: 233-238.

Avila, F., G. Echeverría and D. Pérez. 2015. Serum ferritin is associated with metabolic syndrome and red meat consumption. Oxid. Med. Cell. Longev. 2015: 769739.

Aydin, E., Y. Ramazan, V. Nureddin, G. Hasan and G. Andakin. 1999. Proportionate reduction in all major lipoproteins contributed for the Seruman and lipoprotein profile in children with iron deficiency anemia Pediatrics International. 41: 168-173. 
Bermejo, F and S. García-López. 2009. A guide to diagnosis of iron deficiency and iron deficiency anemia in digestive diseases. World J. Gastroenterol. 15: 4638-4643.

Brill, J.R and D.J. Baumgardner. 2000. Normocytic anemia. Am. Fam. Physician.62: 2255-2264.

Bristow-Craig, H.E., J.J. Strain and R.W. Welch. 1994. Iron status, blood lipids and endogenous antioxidants in response to dietary iron level in male and female rats. Int. J. Vit. Nutr. Res. 64: 324-329.

Cappellini, M.D., K.M. Musallam and A.T. Taher. 2019. Iron deficiency anemia revisited. J. Intern. Med. 287: 153-170.

CDCP. 2008.Centers for Disease Control and Prevention, National Center for Health Statistics. National Health and Nutrition Examination Survey. Available at: www.cdc.gov/nchs/nhanes.htm.

Choi, J.W., S.K. Kim and S.H. Pai. 2001. Changes in serum lipid concentrations during iron depletion and after iron supplementation. Ann. Clin. Lab Sci. 31:151-156.

Chou, R., T. Dana, I. Blazina, M. Daeges, C. Bougatsos and T.L. Jeanne. 2016. Screening for Dyslipidemia in Younger Adults: A Systematic Review for the U.S. Preventive Services Task Force. Ann. Intern. Med. 165: 560-564.

Chowta, N.K., S.B. Reddy, M.N. Chowta, A. Shet, B. Achappa and D.R. Madi. 2017. Lipid profile in anemia: Is there any correlation? Ann. Trop Med. Public Health. 10:837-840.

Cusick, S.E., Z. Mei and D.S. Freedman. 2008.Unexplained decline in the prevalence of anemia among US children and women between $1988-1994$ and $1999-2002$. Am. J. Clin. Nutr. 88:1611-1617.

Douglas, B. K and P. Etheresia. 2014. Serum ferritin is an important inflammatory disease marker, as it is mainly a leakage product from damaged cells. Metallomics. 6: 1-19.

Ece, A., M.R. Yigitoglu, N. Vurgun, H. Güven and A. Iscan. 1999. Serum lipid and lipoprotein profile in children with iron deficiency anemia. Pediatr Int. 41:168-173.

EDHS, Egypt Demographic and Health Survey. 2005. ElZanaty and Ann ed., Ministry of Health and Population, National Population Council, Cairo, Egypt.

Elashiry, A., S. EL Ghazali and I. Habil. 2014.Prevalence and determinants of anemia in third trimester pregnancy in Fayoum Governorate-Egypt. Acta Medica Mediterr. 30: 1045-1051.

Elhassaneen,Y., A. Safaa, S. Ryeaan, F. Naglaa and E. Heba. 2016. Prevalence of Iron-Deficiency Anemia in Infants and Young Children ( $0-6$ Years of Age) of Maternal and Child Care Centers, Port Said Governorate, Egypt. 4th International-18 th Arab Conference of Home Economics "Home Economics and Development Issues" 5-6 April, 2016, Faculty of Home Economics. Minoufiya University, Egypt. Journal of Home Economics (Special issue).26: 7386.

Fahmy, S and A. El-Sherbini. 1983. Determining simple parameters for social classifications for health research. Bull High Inst Public Health. 13:95-108.
Fairbanks, V.F. 1991. Laboratory testing for iron status. Hosp Pract. 26S:17-24.

Gonzales-Requejo, A., M. Sanchez-Bayle and J. Baeza. 1995. Relations between nutrient intake and serum lipid and apolipoprotein levels. J. Pediatr. 127: 53-7.

Graham, R.M., A.C. Chuam, K.W. Carter, R.D. Delima, D. Johnstone and C.E. Herbison. .2010. Hepatic iron loading in mice increases cholesterol biosynthesis. Hepatology, 52:462-71.

Guglielmi, V., M. D'Adamo and A. Bellia. 2015. Iron status in obesity: An independent association with metabolic parameters and effect of weight loss. Nutr. Metab. Cardiovasc Dis. 25: 541-447.

Hafez, M., E.S. Amar, M. Zedan, H. Hammad, A.H. Sorour, E.S. el-Desouky and N. Gamil. 1986. Improved erythrocyte survival with combined vitamin $\mathrm{E}$ and selenium therapy in children with glucose-6-phosphate dehydrogenase deficiency and mild chronic hemolysis. J. Pediatr. 108:558-561.

Hess, S.Y., M.B. Zimmermann and M. Arnold. 2002. Iron deficiency anemia reduces thyroid peroxidase activity in rats. J. Nutr .132:1951-1955

Jingqi, Z., L. Chang, F. Michael, S. Yitang, R. Moon-Suhn, G. Arthur and Y. Kaixiong. 2020.The Causal E_ects of Blood Iron and Copper on Lipid Metabolism Diseases: Evidence from Phenome-Wide Mendelian Randomization Study. Nutrients.12, 3174.

Longo, D.L., A.S. Fauci and D.L. Kasper. 2011. Harrison' principles of internal medicine (hematology disorders). $18^{\text {th }}$ ed. New York: McGraw Hill; pp: 212-215.

Mahshid, S., V. Mohsen, R. Seyed, B. Ali and G. Reza. 2017. Does Serum lipid profile differ in anemia and non-anemic older subjects?. Caspian J. Intern. Med. 8: 305-310.

Mehram, E., S. Sayed-Ahmed and Y. Elhassaneen. 2021. Role of Oxidant/Antioxidant Status in the Pathogenesis of Iron-Deficiency Anemia: Case Study on Children of Qalyubiyya and Minoufiya Governorates, Egypt. Bulletin of the National Nutrition Institute of the Arab Republic of Egypt 55: 39-71.

Mensink, R and M.B. Katan. 1989. Effect of a diet enriched with monounsaturated or polyunsaturated fatty acids on levels of lowdensity and high-density lipoprotein cholesterol in healthy women and men. N. Engl. J. Med. 321: 436-41.

Morrison, J.A., R. Larsen, L. Glatfelter, D. Boggs, K. Burton and C. Smith. 1980. Interrelationships between nutrient intake and plasma lipids and lipoproteins in school children aged 6-19: The Princeton School District Study. Pediatrics. 65: 727-34.

Ohira, Y., V.R. Edgerton, G.W. Gardner and B. Senewiratne. 1980. Serum lipid levels in iron deficiency anemia and effects of various treatments. J. Nutr. Sci. Vitaminol (Tokyo) .26:375-379.

Oski, F. 1993. Iron deficiency in infancy and childhood. N Engl. J.Med. 329:190-193. 
Salonen, J.T., K. Nyyssönen, H. Karpela, J. Tuomilekto, R. Seppanen and R. Salonen.1992. High stored iron levels are ssociated with excess risk of myocardial infarction in Eastern Finnish men. Circulation. 86: 803-811.

Sandeep, N., V.D. Rao, A. Hanumaiah and D. Rampure. 2014. Lipid profile changes in anemia. Transworld Med. J. 2:2932.

Singh, K., K. Sundarro, J. Tinkerame, C. Kaluwin and T. Matsuoka. 1991. Lipid content fatty acid anid mineral composition of Mud Crabs (Seylla serrata) from Papua New Guinea. J. Food Compos. Anal.4 : 276 - 280.

Sotuneh, N., S.R. Hosseinim, J. Shokri-Shirvani, A. Bijani, R. Ghadimi. 2014.Helicobacter pylori infection and metabolic parameters: is there an association in elderly population? Int. J. Prev. Med. 5:1537-1542.

Stroev, E.A and V.G. Makarova. 1989. Laboratory Manual in Biochemistry, MIR Publishers, Moscow, USSR.

Tietz, N.W.1999. Textbook of clinical chemistry, Carl A. Burtis, 3rd ed., WB Saunders, Philadelphia, USA.
Villanova, P.A. 1994. Reference and selected procedures for the quantitative determination of hemoglobin in blood: approved standards. $2^{\text {nd }}$ ed., National Committee for Clinical Laboratory Standards.

Voet, D and J.G. Voet. 1990. Biochemistry. John Wiley and Sons, Inc., New York.

Wang, B., S. Zhan, T. Gong and L. Lee. 2013. Iron therapy for improving psychomotor development and cognitive function in children under the age of three with iron deficiency anemia. Cochrane Database of Systematic Reviews, 6 .

WHO. 2015. The global prevalence of anemia in 2011. World Health Organization, Geneva, Switzerland.

WHO. 2011. Haemoglobin concentrations for the diagnosis of anemia and assessment of severity. Vitamin and Mineral Nutrition Information System. World Health Organization (WHO/NMH/NHD/MNM/11.1), Geneva, Switzerland.

Wu, A., L. Lesperance and H. Bernstein. 2002. Screening for iron deficiency. Pediatrics in Rev. 23: 171-177.

Yang, S., X.Y. Chen and X.P. Xu. 2015. The Relationship Between Lipoprotein-Associated Phospholipase A(2), Cholesteryl Ester Transfer Protein and Lipid Profile and Risk of Atherosclerosis in Women with Iron Deficiency Anemia. Clin. Lab. 61:1463-1469. 


\section{الملخص العربي}

\section{دراسة العلاقة بين الخلل الحادث فى دهون الدم وإنيميا نقص الحديد لدى الأشخاص البالغين

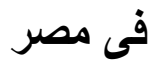

مي عبد الخالق غريب ، ناهد شحاتة عبد العال ، يوسف عبد العزيز الحسانين

| مجم, VI $\pm \mid V, I r, r \leq, T \leq \pm V 1,0 V, r \cdot, 0 \leq$

ديسيلتز بالمقارنة بالقيم المناظرة لدى الاشخاص فى العينة

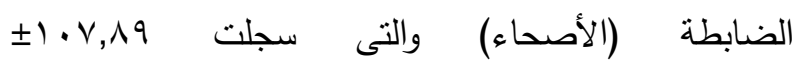

g $11, \leqslant 0 \pm 9 r, r \varepsilon$ ، $r q, r \varepsilon \pm r r, \varepsilon \cdot 610 \Lambda, \leqslant 0$

1, N

كانت اعلى بشكل ملحوظ (PDL-C

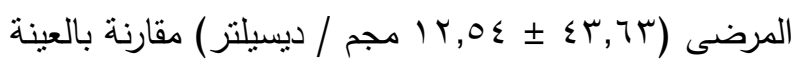

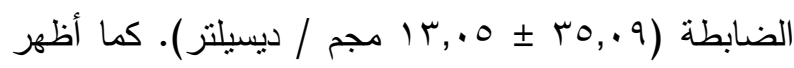

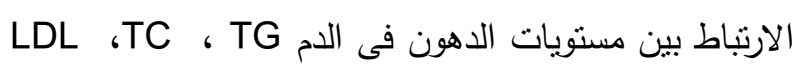

وشدة فقر الدم (مستويات الهيموجلوبين) قيم موجبة ومعنوية

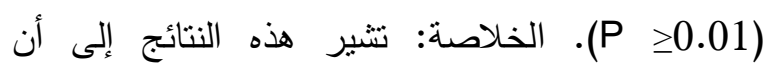

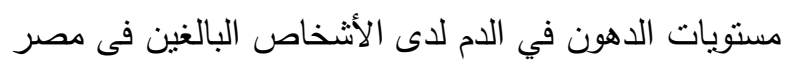

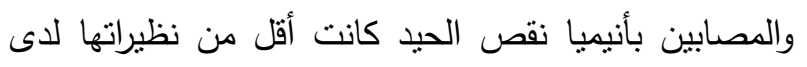
الاثخاص الأصحاء (العينة الضابطة). ومع ذلك ، لتحديد الآليات المحتملة لهذه العلاقة فإنه يوصى بإجراء المزيد من الدراسات على هذا الموضوع فى المستقبل.

الكلمات المفتاحية: انيميا نقص الحديد ، نسبة الدهون في

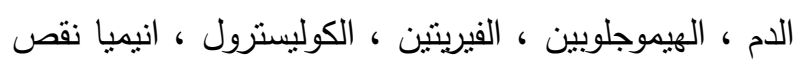

يعتبر كل من فقر الدم الناجم عن انيميا نقص الحديد

والخلل الحادث فى دهون الدم من مشكلات الصحة

العامة السائدة على نطاق واسع فى مختلف انحاء العالم بما فى ذلك مصر • لذلك، كان الغرض من هذا البحث هو دراسة العلاقة بين الخلل الحادث فى دهون الدم وانيميا نقص الحديد لاى الأشخاص البالغين فى محافظة المنوفية بجمهورية مصر العربية. الطريقة: في هذه الدراسة المقارنة المستعرضة، تم فحص عدد •11 من الاشخاص البالغين لديهم انيميا نقص الحديد، وعدد •11 من الاشخاص البالغين الاصحاء

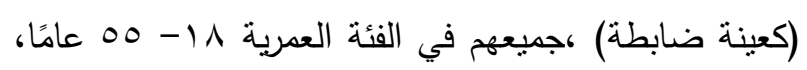
وذلك لمعرفة أي تغييرات محتملة في صورة دهون الدم والتى فيط فئه

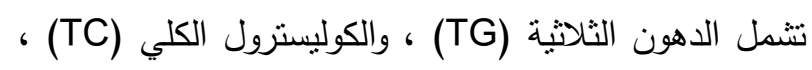
كوليسترول البروتين الدهني عالي الكثافة (HDL-c) وكوليسترول البروتين الدهني منخفض الكثافة (LDL-c) وكوليسترول البروتين الدهني العالى منخفض الكثافة (VLDL-c)

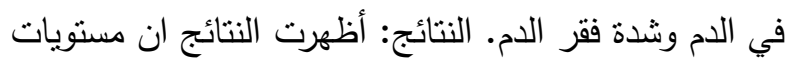
VLDL-C و LDL-C و TC وTG

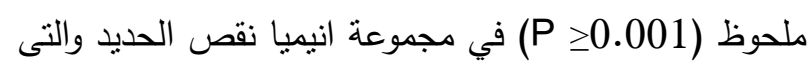

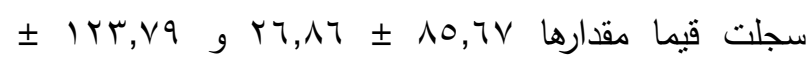

